\title{
Water pollution due to a harmful algal bloom: a preliminary study from two drinking water reservoirs in Kandy, Sri Lanka
}

\author{
S. K. Yatigammana ${ }^{1^{*}}$, O.A. Ileperuma ${ }^{2}$ and M.B.U. Perera ${ }^{1}$ \\ ${ }^{I}$ Department of Zoology, Faculty of Science, University of Peradeniya, Peradeniya. \\ ${ }^{2}$ Department of Chemistry, Faculty of Science, University of Peradeniya, Peradeniya.
}

Submitted: 11 January 2010 ; Accepted: 27 July 2010

\begin{abstract}
A dysenteric epidemic condition occurred in a community of people who consumed water from the two reservoirs, Rosmith and Dunumadalawa in Kandy on $29^{\text {th }}$ and $30^{\text {th }}$ of September 2008 . The symptoms were diarrhoea, vomiting and headache. It was suspected that the epidemic could relate to the water supply from the two reservoirs. To investigate the sources that caused the disease, water samples were analysed for potentially harmful biological organisms. A dinoflagellate species, Peridinium aciculiferum, known to produce a biological toxin under special environmental conditions, was identified for the first time in Sri Lanka from the samples. The relative abundance of $P$. aciculiferum ranged from $\sim 75 \%$ to $100 \%$ of the plankton samples taken from all sites. The abundance and diversity of other organisms at the same trophic level were low and the eutrophication conditions were also predominant in both reservoirs at the time of sampling. It is therefore suggested that $P$. aciculiferum had outcompeted the other planktons in the reservoirs and the epidemic condition had arisen due to the algal toxins present in the reservoirs during the drought period.
\end{abstract}

Keywords: Algal toxins, freshwater dinoflagellates, freshwater red tide, Peridinium aciculiferum, water pollution.

\section{INTRODUCTION}

Deterioration of water quality results from the human activities as well as natural conditions. Increase of nutrient levels, salinity and the accumulation of toxic substances threaten both lentic and lotic freshwater ecosystems worldwide. Reduction of dissolved oxygen also leads to multiple problems including anoxia and nutrient releases from the deep sediments, especially in lentic waters.

The quality of drinking water can be seriously affected due to contamination with various toxic materials. For example, the input of plant nutrients from natural and anthropogenic sources brings about eutrophic conditions, which lead to the formation of algal blooms in water. Such blooms have been observed in Sri Lankan freshwaters, especially during dry periods (Piyasiri, 1995). These blooms are controlled naturally during periods of high rainfall, which leads to high flushing rates of these open water systems. However, in smaller reservoirs constructed in the uplands, flushing rates are low and therefore these are more vulnerable to eutrophication and other related problems.

Some of the algae in these blooms release toxic compounds to water (Rengefors \& Legrand, 2001; Smayda, 1997). These toxins are mainly of three types, neurotoxins, endotoxins and hepatotoxins. The harmful algal blooms are caused mostly by $60-80$ species of phytoplankton and $90 \%$ of them are dinoflagellates (Smayda, 1997). When a dinoflagellate population increases to large numbers, they form red tides and the water is coloured red or brown. The environmental conditions, which result in red tides are not completely understood. Several types of neurotoxins are produced by dinoflagellates and these eventually reach humans through the food chain or municipal water supplies. The freshwater dinoflagellates can cause toxicity in lentic systems when they are in large numbers (Rengefors \& Legrand, 2001; Hirabayashi et al., 2007). Among the toxic dinoflagellates, Peridinium polonicum, P. willei, $P$. volzii and $P$. aciculiferum have been identified in freshwater systems. $P$. willei is often found in temperate freshwaters, especially in drinking water sources (Niese et al., 2007). In addition, several other countries have experienced similar situations and this is now, a major concern internationally. When such algal toxins are present in a drinking water source, it is difficult to save the human population from exposure, especially because many of these algal toxins are not destroyed by boiling.

\footnotetext{
* Corresponding author (sudharma_y@yahoo.com)
} 
In Sri Lanka, hitherto, no detailed work has been carried out on dinoflagellates and also there are no records of red tides. Recently, an epidemic condition occurred in a community which consumed water from two reservoirs, Rosmith and Dunumadalawa in the Kandy city. Several people were admitted to hospitals due to diarrhoea, vomiting, headache and discomfort and it was suspected that this condition is related to the quality of water in the two reservoirs, since a red colouration of water in the margins of Rosmith reservoir had been observed during this period. Therefore, this study was undertaken to investigate the biological, chemical and physical aspects of the water to find the origin of potential toxic substances, which may have caused the ill health condition among the community.

\section{METHODS AND MATERIALS}

\section{Study area:}

(a) Rosmith Reservoir (7N16'44.9, 80E38'39.93): Capacity is $\sim 5670 \mathrm{~m}^{3}$ and is fed by rain water and a small natural stream in the Dunumadalawa forest reserve. This serves as the sole drinking water source to the residents of four villages in the Rajapihilla area of the Kandy city. The reservoir is situated in the middle of a forest reserve and various wild animals including wild boar and wild cats appear to have easy access to the reservoir.

(b) Dunumadalawa Reservoir (7N17'00, 80E38'16.00): The reservoir is established by constructing a dam across the Dunumadalawa stream. The capacity of this reservoir is $185000 \mathrm{~m}^{3}$. It provides $10 \%$ of the water requirements of the Kandy city.

Collection of environmental data: Collection of water samples for analysis of chemical variables from the two reservoirs was carried out $10 \mathrm{~d}$ after the main incident. Water samples from a depth of $\sim 0.5 \mathrm{~m}$ were obtained from 4 sites of each reservoir for the laboratory analysis of nutrients $\left(\mathrm{PO}_{4}^{3-} \& \mathrm{NO}_{3}{ }^{-}\right)$and dissolved oxygen (DO). The samples were collected in $500 \mathrm{~mL}$ acid washed polyethylene bottles that were rinsed with reservoir water prior to sampling. Preservation of water samples followed the APHA (American Public Health Association) standard methods for examination of water and wastewater (APHA, 1992). Samples were stored at $4{ }^{\circ} \mathrm{C}$ and analysis was carried out within $48 \mathrm{~h}$ of obtaining the samples. Phosphate $\left(\mathrm{PO}_{4}^{3-}\right)$ phosphorus was measured colorimetrically using the vanodomolybdate method and nitrate $\left(\mathrm{NO}_{3}^{-}\right)$nitrogen was measured colorimetrically using the cadmium reduction method. DO was measured titrimetrically using the Winkler method.
Site measurements were taken for temperature (T), specific conductance (SC) and salinity using a portable conductivity meter (Thermo Orion- Model 105). Site measurements for $\mathrm{pH}$ from each selected site of both reservoirs were obtained using a portable $\mathrm{pH}$ meter (Orion ${ }^{\odot}$ Model 230A portable $\mathrm{pH}$ meter). The Secchi depth of each reservoir was measured using a $22 \mathrm{~cm}$ diameter Secchi disk. Information of the capacity, maximum depth $\left(Z_{\max }\right)$ and age were obtained from the Kandy Municipal Council.

A plankton net and a dipnet (pore size $50 \mu \mathrm{m}$ ) were used for plankton sampling. Plankton samples were analysed within 2-3 h of sampling using a research microscope (Olympus CX 31) with phase contrast optics. Plankton samples were preserved using Lugols solution and relative abundances of the taxa identified were calculated.

\section{RESULTS AND DISCUSSION}

A margin at the south end of the Rosmith reservoir, the area in which the red colouration had been noticed, was highly contaminated with animal wastes. In addition, the water of the reservoir was greenish brown in colour and highly turbid. Similar conditions were noted from the Dunumadalawa reservoir and floating green coloured mats were also noted in some areas.

\section{Physicochemical analysis}

The environmental parameters measured show that the two reservoirs are moving towards eutrophic conditions (Table 1). Freshwater systems can be considered eutrophic if the total phosphorus levels are higher than $30 \mu \mathrm{g} / \mathrm{L}$. High levels of $\mathrm{PO}_{4}^{3-}$ phosphorus and $\mathrm{NO}_{3}^{-}$ nitrogen $(\mu \mathrm{g} / \mathrm{L})$ suggest that the reservoirs are not nutrient limited systems. Lakes can be phosphorus limited if the total nitrogen: total phosphorus (TN: TP) ratio is more than 17, and nitrogen limited if the ratio is less than 14 (Sakomoto, 1966). In our study, $\mathrm{NO}_{3}{ }^{-}: \mathrm{PO}_{4}{ }^{3-}$ ratios were 15.85 in Dunumadalawa and 72 in Rosmith reservoir. Therefore, it is obvious that both systems are not nitrogen limited. This is a good indication of sewage pollution or the nutrients that have originated from animal or human sources, which is a common phenomenon in Southeast Asia (Osborn, 1991).

Further, oxygen concentrations at the surface level are lower than the average values $(9.5 \mathrm{mg} / \mathrm{L})$ of the Sri Lankan reservoirs (Yatigammana, 2004; Schiemer, 1983). Oxygen depletion of freshwaters occurs mainly because of eutrophic conditions (Wetzel, 2001). 
Therefore, it is suggested that both reservoirs have the problem of eutrophication, which leads to the growth of unwanted algal blooms and toxic conditions to other biota.

Table 1: Environmental data of the two study reservoirs

\begin{tabular}{lcl}
\hline Variable & Dunumadalawa & Rosmith \\
\hline Age (years) & $>100$ & $>100$ \\
Capacity $\left(\mathrm{m}^{3}\right)$ & 185000 & 5670 \\
$\mathrm{Z}_{\text {max }}(\mathrm{m})$ & $\sim 17$ & $\sim 6$ \\
Surface temperature $\left({ }^{\circ} \mathrm{C}\right)$ & $24( \pm 1)$ & $25( \pm 1)$ \\
Specific conductance $(\mathrm{SC})(\mu \mathrm{S} / \mathrm{cm})$ & $65( \pm 2)$ & $80( \pm 3)$ \\
Dissolved oxygen $(\mathrm{DO}) \mathrm{mg} / \mathrm{L}($ average$)$ & 7.52 & 6.27 \\
$\mathrm{pH}($ average) & 7.47 & 7.63 \\
$\mathrm{Secchi}$ depth $(\mathrm{cm})$ & $50( \pm 2)$ & $25( \pm 2)$ \\
$\mathrm{PO}_{4}^{3-}$ Phosphorus $(\mu \mathrm{g} / \mathrm{L})($ average $)$ & 26 & 17 \\
$\mathrm{NO}_{3}^{-}$Nitrogen $(\mu \mathrm{g} / \mathrm{L})($ average $)$ & 412 & 1227 \\
$\mathrm{NO}_{3}^{-}: \mathrm{PO}_{4}^{3-}$ & 15.85 & 72 \\
\hline
\end{tabular}

\section{Biological analysis}

Planktonic organisms were identified from microscopic examination of the samples obtained from both reservoirs, and a phytoflagellate species was the most abundant. In all water samples obtained from the two reservoirs, a dinoflagellate, $P$. aciculiferum was identified (Figures $1 \& 2$ ). The relative abundance of this particular species is different for the two reservoirs.

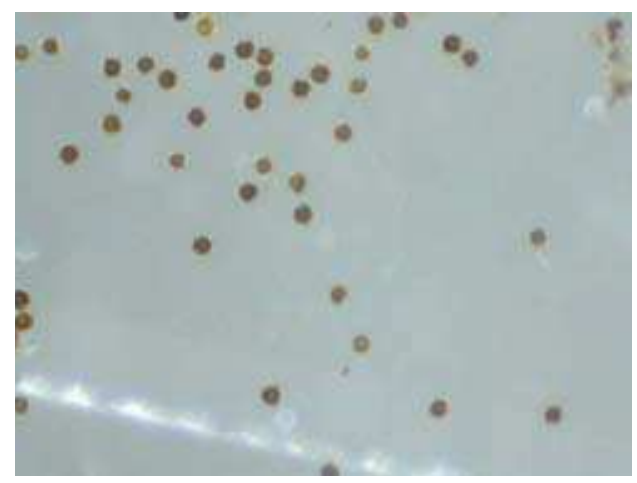

Figure 1: $P$. aciculiferum at $4 \times 10$ magnification

At some sampling sites, the relative abundance was more than $99 \%$ and at other sites it was slightly lower, but not less than $75 \%$. When the water samples were examined immediately after they were brought to the laboratory, flagellate movements were clearly visible. The images of the $P$. aciculiferum identified in previous studies (Rengefors \& Legrand, 2001) matched with our observations.
According to previous studies on Sri Lankan reservoirs (Yatigammana, 2004; Bauer, 1983), a majority of the reservoirs are stratified due to thermal, chemical and morphometric characteristics. The wet zone reservoirs in Sri Lanka, in particular, are identified as stratified due to these factors. Under such conditions, lentic waters can become meromictic (partially mixing) with two layers, mixolimnion (upper mixing layer) and monimolimnion (lower non-mixing layer) of the water column. The bottom non mixing layer could remain permanently anoxic and can be an unfriendly environment to many aquatic organisms, especially phytoplanktons. Low Secchi depth values recorded from the study sites also suggest that the photic zone (trophogenic zone), the depth of the water column where the photosynthesis is greater than respiration, is limited to topmost layers. Therefore, it is proposed that primary production of these reservoirs is limited to the uppermost layers of the water column. In addition, the existence of bottom anoxia can govern the distribution of biota and lead to reduction of the number of habitats present in such systems. These conditions also force the aquatic biota to remain in the surface layers, which will ultimately lead to increased competition. Studies have found that dissolved oxygen (DO) in water was a determinant factor for completion of the life cycle of Peridinium species (Kida et al., 1989). Therefore, it is obvious that such organisms prefer to inhabit surface water columns where oxygen rich environments exist. Hence, it can be suggested that the behavioural and physiological adaptations force dinoflagellates to remain in the upper layers of the water column where the DO

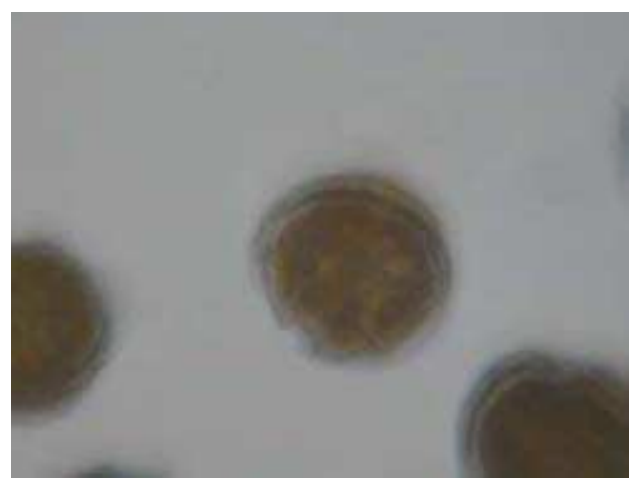

Figure 2: $P$. aciculiferum at $40 \times 10$ magnification

is not limited. Similar environmental conditions may have influenced the high abundance and aggregation of $P$. aciculiferum in the reservoirs studied, especially in the Dunumadalawa reservoir, which can be considered as a deep system $\left(Z_{\max } \sim 17 \mathrm{~m}\right)$. It has been found that another species of Peridinium (P. bipes) responds to the variation of environmental variables such as conductivity, $\mathrm{pH}$ and transparency (Hirabayashi et al., 2007). In 
addition, environmental preferences of dinoflagellates show that they prefer lower turbidity and high nutrient concentrations (Smayda, 1997). In the presence of high nutrient concentrations, the cellular growth of all plankton increase and then the turbidity also increases. When the turbidity increases, it will ultimately lead to an unfavourable environment for dinoflagellates. Under such conditions, they tend to aggregate and produce toxins, which are lethal to other organisms in the environment.

When dinoflagellates aggregate in high densities $\left(>1100 \quad\right.$ cells $\left./ \mathrm{cm}^{3}\right)$, they form red tides (Hirabayashi et al., 2007). Our analysis also indicated a high dominance of P. aciculiferum (i.e. $>1000$ cells $/ \mathrm{cm}^{3}$ ) while the other plankton density was about $100 \mathrm{cell} / \mathrm{s} / \mathrm{cm}^{3}$. Similar situations were present in both reservoirs. Therefore, the red colouration, which appeared along a margin of the Rosmith reservoir could be an indication of the high abundance of $\mathrm{P}$. aciculiferum. In toxic red tides, dinoflagellates produce a chemical, which acts as a neurotoxin and could be fatal to other animals (Rengefors \& Legrand, 2001). P. aciculiferum, is known to produce an allelopathic substance which inhibits the growth of other competing organisms. In addition, some dinoflagellates produce predator defense toxins to reduce the growth of larval forms of fish and crustaceans (Rengefors \& Legrand, 2001). When a planktonic organism produces a toxin of any kind, there is a high tendency for its bioaccumulation through the food chain. Additionally, these compounds can persist within the water column. All these factors together could severely affect the ecological balance of the system.

Our environmental examinations indicate that both reservoirs are likely to have been contaminated with animal wastes and therefore the reservoirs have the potential for the input of high loads of nutrients such as phosphorus and nitrogen. In addition, Dunumadalawa reservoir is situated at a lower altitude and a human community inhabits the catchment. Therefore, it appears to receive a significant amount of anthropogenic wastes, both organic and inorganic, leading to eutrophication and mass blooming of nuisance algae and toxin releasing dinoflagellates. All these factors suggest that the red colouration, which appeared in the Rosmith reservoir before the onset of rain could have caused the water poisoning incident in Kandy. The presence of the same species of dinoflagellate at a high density in Dunumadalawa reservoir also points to the occurrence of a similar situation.

\section{Acknowledgement}

We thank the Provincial Director of Health services
Dr. S. A. K. Gamage and the Regional epidemiologist Dr. Chandana Wijesinghe, for bringing this incident to our attention.

\section{References}

1. American Public Health Association (APHA) (1992). Standard Methods for Examination of Water and Wastewater, $18^{\text {th }}$ edition. American Public Health Association, Washington DC, USA.

2. Bauer K. (1983). Thermal stratification, mixis and adjective currents in the Parakrama Samudra reservoir, Sri Lanka. Limnology of Parakrama Samudra (ed. F. Schiemer), pp. 27-31. Dr. W. Junk Publishers, The Hague, The Netherlands.

3. Hirabayashi K., Yoshizawa K., Yoshida N., Arizumi K. \& Kazama F. (2007). Long - term dynamics of freshwater red tide in shallow lake in Central Japan. Environmental Health and Preventive Medicine 12(1): 33-39.

4. Kida K., Park H.D. \& Hayashi H. (1989). Occurrence of freshwater red tide of Peridinium spp. in Lake Kizaki. Journal of the Faculty of Science Shinshu University 24 (1): 13-25.

5. Niesel V., Hoehn E., Sudbrack R., Willmitzer H. \& Chorus I. (2007). The occurrence of the Dinophyte species Gymnodinium uberrimum and Peridinium willei in German reservoirs. Journal of Plankton Research 29 (4):347-357.

6. Osborn P.L. (1991). Seasonality in nutrient and phytoplankton production in two shallow lakes: Waigani Lake, Papua New Guinea, and Braton Broad, Norfolk, England. International Reviews of Hydrobiology 76(1): 105-112.

7. Piyasiri S. (1995). Eutrophication and blue green algal bloom problem of Kothmale Reservoir in Sri Lanka. Tropical Limnology (eds. K.H. Timotius \& F. Goltenboth), volume 2. Satya Wacana University Press, Salatiga, Indonesia.

8. Rengefors K. \& Legrand C. (2001). Toxicity in Peridinium aciculiferum - an adaptive strategy to outcompete other winter phytoplankton. Limnology and Oceanography 46(8): 1990-1997.

9. Sakomoto M. (1966). Primary production by phytoplankton community in some Japanese lakes and its dependence on lake depth. Archives of Hydrobiology 62(1): 1-28.

10. Schiemer F., ed. (1983). Limnology of Parakrama Samudra, Sri Lanka: A Case Study of an Ancient Man Made Lake in the Tropics, pp.236. Dr. W. Junk Publishers, The Hague, The Netherlands.

11. Smayda T.J. (1997). Harmful algal blooms: their ecophysiology and general relevance to phytoplankton blooms in the sea. Limnology and Oceanography 42(5): 1137:1153.

12. Wetzel R.G. (2001). Limnology: Lakes and River Ecosystems, p. 1006. Academic Press, San Diego, USA.

13. Yatigammana S.K. (2004). Development and application of paleoecological approaches to study the impacts of anthropogenic activities on reservoirs in Sri Lanka. Ph.D thesis, Queens University, Kingston, Canada. 